\title{
Knowledge of and Attitude Toward Leprosy in a Leprosy Endemic District, Eastern Ethiopia: A Community-Based Study
}

This article was published in the following Dove Press journal: Risk Management and Healthcare Policy

\author{
Kedir Urgesa' \\ Kidist Bobosha ${ }^{2}$ \\ Berhanu Seyoum ${ }^{2}$ \\ Biftu Geda $\left.{ }^{3}\right)^{3}$ \\ Fitsum Weldegebreal $\mathbb{1 D}^{3}$ \\ Adane Mihret ${ }^{2}$ \\ Rawleigh Howe ${ }^{2}$ \\ Mirgissa Kaba $\mathbb{D}^{4}$ \\ Abraham Aseffa ${ }^{2}$ \\ 'Department of Medical Laboratory \\ Sciences, College of Health and Medical \\ Sciences, Haramaya University, Harar, \\ Ethiopia; ${ }^{2}$ Armauer Hansen Research \\ Institute, Addis Ababa, Ethiopia; ${ }^{3}$ College \\ of Health and Medical Sciences, \\ Haramaya University, Harar, Ethiopia; \\ ${ }^{4}$ School of Public Health, Addis Ababa \\ University, Addis Ababa, Ethiopia
}

Introduction: Leprosy or Hansen's disease is a potentially disabling disease that results in discrimination and self-stigma. A delay in case detection among leprosy patients is one of the factors resulting in disability. Although poor insights of the community toward leprosy lead to delays in case detection, studies on such matters are neglected in Ethiopia.

Objective: To assess the level of community knowledge and attitudes toward leprosy in Fedis District, Eastern Ethiopia.

Methods: A community-based cross-sectional study was carried out among 728 randomly selected households from July to August 2019. Each participant was interviewed using a pretested structured questionnaire consisting of participants' socio-demographic background, questions related to knowledge of and attitudes toward leprosy. The collected data were entered using EpiData 3.1 and analyzed using STATA version 13. Chi-squared test, binary, and multivariable logistic regressions were applied as appropriate to assess the association between outcome and independent variables.

Results: Among 728 study participants, 608 (83.52\%) of them had heard about leprosy. Among the study participants who had heard of leprosy, 346 (56.91\%) of them had high knowledge of leprosy. Multivariable logistic regression revealed that study participants who completed grade $1-8(\mathrm{AOR}=1.68,95 \% \mathrm{CI}=1.09-2.58, \mathrm{P}=0.017)$ and government employees $(\mathrm{AOR}=7.56,95 \%$ $\mathrm{CI}=2.23-25.63, \mathrm{P}=0.001)$ were significantly associated with high level of knowledge of leprosy. Out of 608 study participants who had heard of leprosy, only $248(40.79 \%)$ had a favorable attitude toward leprosy. Study participants who completed grade $1-8$ (AOR $=2.72,95 \%$ $\mathrm{CI}=1.76-4.19, \mathrm{P}=0.000)$ and urban inhabitants $(\mathrm{AOR}=0.49,95 \% \mathrm{CI}=0.31-0.75, \mathrm{P}=0.032)$ were significantly associated with favorable attitude toward leprosy. Having high knowledge of leprosy was significantly associated with favorable attitudes toward leprosy.

Conclusion: This study revealed unfavorable attitudes toward leprosy among the community. Having a high overall knowledge level on leprosy has been shown to support a favorable attitude toward leprosy.

Keywords: leprosy, knowledge, attitude, endemic, Ethiopia

\section{Introduction}

Leprosy, also called Hansen's disease, is among the oldest infectious diseases known to human beings and one of the world's neglected tropical diseases. ${ }^{1,2}$ It is also a leading cause of preventable disability worldwide. ${ }^{3}$ Leprosy-associated disability is known to result in discrimination and self-stigma that has overwhelmed creatures throughout centuries. ${ }^{1,4}$ Besides, this disability can hamper persons' activities, social involvement, and cause physical dysfunction. ${ }^{5}$
Correspondence: Kedir Urgesa

P.O Box 235, Harar, Ethiopia

$\mathrm{Tel}+251940635596$

Email kedirbofe@gmail.com 
Although the prevalence of leprosy in Ethiopia has declined over time after the introduction of effective multidrug therapy, the emergence of new cases is still challenging for the national health sectors. ${ }^{6}$ In Ethiopia, the presence of stigmatizing attitudes toward leprosy patients was also indicated. $^{7}$ Pessimistic insight of the community toward leprosy would negatively affect the quality of life for leprosy patients. ${ }^{8}$ Leprosy patients with negative perceptions also go undiagnosed for a long period, which favors the continuous transmission of infection and permits progression of the disease and more severe disability.,

Strengthening the patient and community awareness of leprosy is one of the key interventions to control leprosy and its complications. ${ }^{9}$ In addition, enhancing positive attitudes toward leprosy-affected persons can reduce the community stigma and increase their early health-seeking behavior and their quality of life. ${ }^{10}$ Furthermore, filling the community knowledge gaps through education can reduce their misconceptions and positively influence the perception of leprosy. ${ }^{11}$

However, community-based awareness of leprosy for better control and prevention of leprosy in Ethiopia has been neglected and not sufficiently studied. ${ }^{6}$ Therefore, we aimed to assess the level of community knowledge and attitude toward leprosy in a leprosy endemic district in eastern Ethiopia.

\section{Methods}

\section{Study Design and Setting}

A community-based cross-sectional study was conducted in Fedis District, East Hararghe Zone. Fedis is one of the leprosy endemic districts with a total population estimated to be 133,382 persons in $2014 .^{12}$ The district contains 19 rural and 2 urban villages with altitudes ranging from 1050 to 2118 meters above sea level. ${ }^{13}$ During the study period, in the district, five health centers were providing general health services including, tuberculosis and leprosy control activities. According to the Zonal Health Office report, in 2017, a total of 57 new leprosy cases were on treatment, which indicates a 4.3/10,000 prevalence. ${ }^{14}$ The study was conducted from July 1 to August 31, 2019 in both urban villages and four randomly selected rural villages.

\section{Study Participants}

The study population was households in Fedis District. All those 18 years and older, who have been inhabitants of the selected villages for more than 6 months, were included in the study. All health care professionals were excluded from the study.

\section{Sample Size and Sampling Procedure}

The sample size was calculated using Statcalc Epi-Info considering the proportion of the community with high knowledge (19.3\%) from a previous study. ${ }^{15}$ By assuming a $3 \%$ margin of error, and a $10 \%$ non-response rate, the final calculated sample size was 728 . The sample was allocated to each village, proportional to its population size. Using the lists of the households obtained from the health extension workers, a simple random sampling was used to select households for inclusion. Within the household, a lottery method was applied to select one respondent aged 18 years or older for the interview.

\section{Study Variables}

The dependent variables of the study were knowledge and attitude regarding leprosy. The independent variables were participants' gender, age, marital status, educational status, occupation, religion, ethnicity, and residence.

\section{Data Collection Tool and Procedure}

Structured quantitative questionnaire was used in this study. This questionnaire was adapted from tools used by Tesema ${ }^{15}$ and later validated by Atinkut. ${ }^{7}$ The questionnaire contains three parts: the first part was participants' socio-demographic characteristics including, gender, age, religion, ethnicity, educational status, occupation, and residence; the second part included 7 items to assess knowledge of the participants, and the third part included 8 items to assess participants' attitudes toward leprosy. The questionnaire was prepared in English and translated into Afan Oromo and back-translated into English. The questionnaire was pre-tested among $5 \%$ of the non-selected village communities in the same district and adjusted accordingly.

A total of six trained health extension workers collected the data under the supervision of KU and two public health officers. The interview was face-to-face through house-to-house visits using the local language.

\section{Data Processing and Analysis}

The collected data were entered using EpiData 3.1 (Odense, Denmark) and analyzed using STATA 13 (StataCorp LP., College Station, TX, USA). Descriptive statistics like mean, percentages, and proportions were used. Chi-squared test, binary, and multivariable logistic regression were applied as appropriate to assess the 
association between knowledge and attitude and the independent variables. The results were considered statistically significant when $P$ values $<0.05$ were obtained.

\section{Ethical Consideration}

This study was conducted in accordance with the Declaration of Helsinki and Ethiopia research regulations. It was reviewed and approved by the Institutional Health Research Ethics Review Committee (IHRERC), College of Health and Medical Sciences, Haramaya University (ref no: IHRERC/ 152/2018), and the Armauer Hansen Research Institute Ethics Committee (ref no: P002/18 AHRI/ERC). Permission was obtained to conduct the study from the Oromia Regional Health Bureau, East Hararghe Zone, Fedis District Health offices, and village leaders. Study participants were given information about the objectives of the study and informed, voluntary, written, and signed consent was obtained. All data were anonymized, and the confidentiality of study participants was strictly respected during data processing and analysis.

\section{Results}

\section{Socio-Demographic Characteristics of the Study Participants}

All the 728 respondents approached were consented and included in this study. The mean $( \pm \mathrm{SD})$ age of participants was $33.2 \pm 8$ years, range $18-80$ years. Nearly half $(50.27 \%)$ of the participants were female and $70.47 \%$ were from a rural residence (Table 1).

\section{Knowledge Regarding Leprosy}

Out of the 728 study participants, $608(83.52 \%)$ of them had heard about leprosy. The remaining 120 (16.48\%) study participants who had no information about leprosy were excluded from the analysis. For those who had heard of leprosy, their main sources of information were mainly mass media 333 (54.77\%) and formal school 118 (19.41\%). Less than one-third (30.92\%) of the participants stated that bacteria was the causative agent of leprosy and $256(42.11 \%)$ of them considered leprosy a hereditary disease. Slightly lower than one in five $(17.93 \%)$ of study participants reported that leprosy is a curse from God and $100(16.45 \%)$ perceived that it is a punishment for the sin of the family. Concerning the leprosy cardinal symptoms, 257 (42.77\%) and $121(19.90 \%)$ of them reported that leprosy causes skin itching and always results in deformity, respectively.

Prolonged contact with leprosy patients was stated as the main route of transmission by $221(36.35 \%)$ of study
Table I Socio-Demographic Characteristics of the Study Participants Among Fedis District Community from July to August, $2019(n=728)$

\begin{tabular}{|c|c|c|c|}
\hline Variables & $\begin{array}{l}\text { Variables } \\
\text { Category }\end{array}$ & $\begin{array}{l}\text { Numberl } \\
\text { Frequency }\end{array}$ & Percent \\
\hline Sex & $\begin{array}{l}\text { Male } \\
\text { Female }\end{array}$ & $\begin{array}{l}362 \\
366\end{array}$ & $\begin{array}{l}49.73 \\
50.27\end{array}$ \\
\hline $\begin{array}{l}\text { Age of } \\
\text { subjects }\end{array}$ & $\begin{array}{l}18-30 \text { years } \\
31-45 \text { years } \\
\text { Above } 45\end{array}$ & $\begin{array}{l}367 \\
309 \\
52\end{array}$ & $\begin{array}{l}50.41 \\
42.45 \\
7.14\end{array}$ \\
\hline Religion & $\begin{array}{l}\text { Muslim } \\
\text { Orthodox } \\
\text { Protestant }\end{array}$ & $\begin{array}{l}688 \\
31 \\
9\end{array}$ & $\begin{array}{l}94.51 \\
4.26 \\
1.24\end{array}$ \\
\hline Ethnicity & $\begin{array}{l}\text { Oromo } \\
\text { Amahara } \\
\text { Gurage } \\
\text { Harari }\end{array}$ & $\begin{array}{l}654 \\
39 \\
14 \\
21\end{array}$ & $\begin{array}{l}89.84 \\
5.36 \\
1.92 \\
2.88\end{array}$ \\
\hline Marital status & $\begin{array}{l}\text { Single } \\
\text { Married } \\
\text { Separated }\end{array}$ & $\begin{array}{l}98 \\
589 \\
41\end{array}$ & $\begin{array}{l}13.46 \\
80.9 \mid \\
5.63\end{array}$ \\
\hline $\begin{array}{l}\text { Educational } \\
\text { status }\end{array}$ & $\begin{array}{l}\text { No formal } \\
\text { education } \\
\text { Grade I-8 } \\
\text { Secondary school \& } \\
\text { above }\end{array}$ & $\begin{array}{l}499 \\
143 \\
86\end{array}$ & $\begin{array}{l}68.54 \\
19.64 \\
11.81\end{array}$ \\
\hline Occupation & $\begin{array}{l}\text { Farmer } \\
\text { House wife } \\
\text { Merchant } \\
\text { Government } \\
\text { employee } \\
\text { Others* }\end{array}$ & $\begin{array}{l}504 \\
109 \\
31 \\
65 \\
19\end{array}$ & $\begin{array}{l}69.23 \\
14.97 \\
4.26 \\
8.93 \\
2.61\end{array}$ \\
\hline Residence & $\begin{array}{l}\text { Rural } \\
\text { Urban }\end{array}$ & $\begin{array}{l}513 \\
215\end{array}$ & $\begin{array}{l}70.47 \\
29.53\end{array}$ \\
\hline
\end{tabular}

Note: *Students and unemployed.

participants. Among the study participants who had heard about leprosy, $226(37.17 \%)$ of them accurately responded that leprosy can be transmitted through aerosol droplets from patients. The majority, 472 (77.63\%), of the study participants responded that leprosy is a curable disease and most, 550 (90.46\%), of them suggested that leprosy can be cured by modern medicine (Table 2).

The overall knowledge of leprosy was assessed using a scoring system. A score of 1 was given to correct responses, and 0 was used for incorrect/do not know responses. A sum score was constructed by adding the items corresponding to each variable and a mean value was used to categorize the study participants into two categories. ${ }^{7,15}$ Accordingly, those 
Table 2 Knowledge of Leprosy Among Study Participants in Fedis District from July to August, 2019 ( $n=608)$

\begin{tabular}{|c|c|c|c|}
\hline Knowledge Related Questions & Response & Frequency & Percentage \\
\hline \multirow[t]{2}{*}{ Have you heard about leprosy? } & Yes & 608 & 83.52 \\
\hline & No & 120 & 16.48 \\
\hline \multirow[t]{5}{*}{ Where did you hear about leprosy? } & Mass media & 333 & 54.77 \\
\hline & Family member & 97 & 15.95 \\
\hline & Health worker & 118 & 19.41 \\
\hline & Friends & 87 & $|4.3|$ \\
\hline & Do not remember & 1 & 0.16 \\
\hline \multirow[t]{8}{*}{ What causes leprosy? } & Punishment for sin of family & 100 & 16.45 \\
\hline & Due to curse by God & 109 & 17.93 \\
\hline & Immoral conduct & 37 & 6.09 \\
\hline & Hereditary cause & 256 & 42.11 \\
\hline & Unclean environment cause & 72 & 11.84 \\
\hline & Bacterial cause & 188 & 30.92 \\
\hline & Cold food cause & 57 & 9.38 \\
\hline & Bad blood cause & 6 & 0.99 \\
\hline \multirow[t]{6}{*}{ What is/are symptoms of leprosy? } & It causes skin irritation & 257 & 42.27 \\
\hline & It can present as skin patches & 310 & 50.99 \\
\hline & Loss of sensation & 265 & 43.59 \\
\hline & It can lead to deformities or & 102 & 16.78 \\
\hline & $\begin{array}{l}\text { disal } \\
\text { urement }\end{array}$ & & \\
\hline & Always deformity & 121 & 19.90 \\
\hline \multirow[t]{7}{*}{ What is/are means of leprosy transmission? } & Aerosol droplets & 226 & 37.17 \\
\hline & Casual contact & 140 & 23.03 \\
\hline & Contaminated water and soil & 45 & 7.40 \\
\hline & Sexual contact & 113 & 18.59 \\
\hline & Prolonged contact & 221 & 36.35 \\
\hline & Site beside patient & 63 & 10.36 \\
\hline & Share items with patient & 87 & $|4.3|$ \\
\hline \multirow[t]{4}{*}{ Is leprosy cured? } & Yes & 472 & 77.63 \\
\hline & No & 54 & 8.88 \\
\hline & Sometimes & 64 & 10.53 \\
\hline & I do not know & 18 & 2.96 \\
\hline \multirow[t]{4}{*}{ What is/are the treatment of leprosy? } & Pharmaceutical drugs & 550 & 90.46 \\
\hline & Traditional mode of treatment & 78 & 12.83 \\
\hline & Religious ritual treatment & 44 & 7.24 \\
\hline & I do not know treatment option & 13 & 2.14 \\
\hline
\end{tabular}

who scored above or equal to the mean value were considered as having high overall knowledge, while those who scored below the mean were considered as having low overall knowledge. In this study, knowledge scores of the participants ranged from 3 to 13 and the mean $( \pm \mathrm{SD})$ knowledge score was $7.35 \pm 1.57$.

Overall, 346 (56.91\%) of the participants had a high level of knowledge regarding leprosy. In a multivariable regression analysis, study participants who completed at least
Grade $1-8(\mathrm{AOR}=1.68,95 \% \mathrm{CI}=1.09-2.58, \mathrm{P}=0.017)$ and who were employed (AOR=7.56, 95\% $\mathrm{CI}=2.23-25.63$, $\mathrm{P}=0.001$ ) were significantly associated with having a high knowledge of leprosy (Table 3).

\section{Attitude Toward Leprosy}

Among the study participants who had heard about leprosy, 270 (44.41\%) believed that it was shameful to share public transport with leprosy patients. Only 103 
Table 3 Association Between Knowledge of Leprosy and Socio-Demographic Characteristics of Study Participants in Fedis District, from July to August, $2019(n=608)$

\begin{tabular}{|c|c|c|c|c|c|}
\hline \multirow[t]{2}{*}{ Variables } & \multirow[t]{2}{*}{ Category } & \multicolumn{4}{|c|}{ Overall Knowledge Regarding Leprosy } \\
\hline & & Low, $\mathbf{N}(\%)$ & High (\%) & COR $(95 \% \mathrm{Cl})$ & AOR $(95 \% \mathrm{Cl})$ \\
\hline \multirow[t]{2}{*}{ Sex } & Male & $127(48.47)$ & $194(56.07)$ & 1 & \\
\hline & Female & $135(5 \mid .53)$ & $152(43.93)$ & $0.73(0.53-1.01)^{*}$ & $0.81(0.56-1.15)$ \\
\hline \multirow[t]{3}{*}{ Age in years } & $18-30$ & $127(48.47)$ & $175(50.58)$ & 1 & \\
\hline & $31-45$ & $123(46.95)$ & 147(42.49) & $0.86(0.62-1.20)$ & \\
\hline & $>45$ & $12(4.58)$ & $24(6.94)$ & $1.45(0.69-3.01)$ & \\
\hline \multirow[t]{3}{*}{ Current marital status } & Never married & $32(|2.2|)$ & $50(14.45)$ & 1 & \\
\hline & Married & $217(82.82)$ & $278(80.35)$ & $0.8 \mathrm{I}(0 \mathrm{0} 0.50-1.32)$ & \\
\hline & Separated & $13(4.96)$ & $18(5.20)$ & $0.88(0.38-2.05)$ & \\
\hline \multirow[t]{3}{*}{ Educational status } & No formal education & $191(72.90)$ & $217(62.72)$ & 1 & \\
\hline & Grade I-8 & $46(17.56)$ & $8 I(23.4 I)$ & $1.54(1.02-2.33)^{*}$ & $1.68(1.09-2.58)^{* *}$ \\
\hline & Secondary \& above & $25(9.54)$ & $48(13.87)$ & $1.68(1.00-2.84)^{*}$ & $0.39(0.13-1.18)$ \\
\hline \multirow[t]{5}{*}{ Occupation } & Farmer & $189(72.14)$ & $246(71.10)$ & 1 & \\
\hline & Housewife & 44 (16.79) & $4 \mathrm{I}(1 \mathrm{I} .85)$ & $0.7 \mathrm{I}(0.44-\mathrm{I} .14)^{*}$ & $0.75(0.45-1.24)$ \\
\hline & Merchant & $10(3.82)$ & $10(2.89)$ & $0.76\left(\begin{array}{ll}0 & 0.3 I-1.88\end{array}\right)$ & $0.63(0.24-1.62)$ \\
\hline & Government Employee & $12(4.58)$ & $47(13.58)$ & $3.00(1.55-5.83)^{*}$ & $7.56(2.23-5.63)^{* *}$ \\
\hline & Others & 7 (2.67) & $2(0.58)$ & $0.2 \mathrm{I}(0.04-1.06)^{*}$ & $0.8 I\left(\begin{array}{ll}0 & 0.14-4.75\end{array}\right)$ \\
\hline \multirow[t]{2}{*}{ Residence } & Rural & 191 (72.90) & $265(76.59)$ & 1 & \\
\hline & Urban & 71 (27.10) & $8 I(23.4 I)$ & $0.82(0.56-1.18)$ & \\
\hline
\end{tabular}

Notes: Statistically significant difference* $(\mathrm{P}<0.25)$, ** $(\mathrm{P}<0.05)$.

Abbreviations: $\mathrm{COR}$, crude odds ratio; $\mathrm{AOR}$, adjusted odds ratio; $\mathrm{Cl}$, confidence interval.

(16.94\%) of the study participants would allow their children to marry someone from a family who had a history of leprosy. A quarter, 155 (25.49\%), of the study participants would allow their children to play with children from a family who had a history of leprosy. More than half, 341 (56.09\%), of the participants would feel innocent to work with some who have leprosy in the same environment; although about $400(65.79 \%)$ of them would feel ashamed to have someone with leprosy in their family. About half, 298 (49.01\%), of study participants would allow sharing dishes/plates with leprosy patients (Table 4).

Attitudes regarding leprosy were assessed using a scoring system. A score of 1 was given to correct responses, and 0 was used for incorrect/"do not know" responses. A sum score was constructed by adding the items corresponding to each variable and a mean value was used to categorize the study participants into two categories. $^{7,15}$ Accordingly, those who scored above or equal to the mean value were considered as having favorable attitude, while those who scored below the mean value were considered as having unfavorable attitude. In this study, attitude scores of the respondents ranged from 9 to 24 and the mean $( \pm \mathrm{SD})$ attitude score was $14.25 \pm$ 2.63. Among 608 study participants who had heard of leprosy, $248(40.79 \%)$ had a favorable attitude toward the disease.

\section{Independent Predictors of Attitudes Toward Leprosy}

Study participants who thought leprosy was transmitted by casual contact with leprosy patients were more likely to have 2.84 times higher attitude that, not to admit sitting beside leprosy patients in public transport. Participants who thought leprosy was a hereditary disease were more likely to have a two times higher chance of being ashamed if someone in their family had leprosy. Also, study participants who thought leprosy was due to prolonged contact were more likely to have a 1.59 times higher chance of being ashamed to work with leprosy patients in the same environment. Participants who thought leprosy was a curse were more likely to have a 3.49 times higher chance of not allowing their own child to play with a child from a family with a leprosy history (Table 5). 
Table 4 Attitude toward Leprosy Among Study Participants in Fedis District from July to August, 2019 ( $n=608)$

\begin{tabular}{|c|c|c|c|}
\hline \multirow[t]{2}{*}{ Attitude Related Questions } & \multicolumn{3}{|l|}{ Response } \\
\hline & Yes N (\%) & No $\mathbf{N}(\%)$ & I Do Not Know N (\%) \\
\hline Would you admit to sitting beside a leprosy patient in public transport? & $309(50.82)$ & $270(44.41)$ & $29(4.77)$ \\
\hline Would you be ashamed if someone has leprosy in your family? & $400(65.79)$ & $175(28.78)$ & $33(5.43)$ \\
\hline Would you admit to sharing a plate with a leprosy patient? & $298(49.01)$ & $278(45.72)$ & $32(5.26)$ \\
\hline Would you admit to owning a child who married someone from a family with a history of leprosy? & $103(16.94)$ & 471 (77.47) & $34(5.59)$ \\
\hline Would you be ashamed to work with a leprosy patient in the same environment? & $225(37.01)$ & $34 I(56.09)$ & $42(6.91)$ \\
\hline Would you allow your own child to play with a child from leprosy family? & 155(25.49) & 417 (68.59) & $36(5.92)$ \\
\hline Would you admit to helping if someone gets leprosy in the family? & $513(84.38)$ & $73(12.01)$ & $22(3.62)$ \\
\hline Would you share items with a leprosy patient? & $25 I(4 I .28)$ & $337(55.43)$ & $20(3.29)$ \\
\hline
\end{tabular}

In a multivariable regression analysis, study participants who completed Grade 1-8 (AOR $=2.72,95 \%$ $\mathrm{CI}=1.76-4.19, \quad \mathrm{P}=0.000)$ were associated with a favorable attitude. Urban inhabitants $(\mathrm{AOR}=0.49,95 \%$ $\mathrm{CI}=0.31-0.75, \mathrm{P}=0.032)$ were associated with an unfavorable attitude (Table 6). Moreover, having a high level of knowledge was significantly associated with a favorable attitude toward leprosy $\left(\mathrm{X}^{2}=55.9063, \mathrm{P}=0.001\right)$.

\section{Discussion}

This study was conducted to assess the level of knowledge and attitude toward leprosy in leprosy "hotspot" district in eastern Ethiopia. We found that $56.91 \%$ and $40.79 \%$ of the participants had a high level of knowledge and favorable attitude toward leprosy, respectively. Having a high overall knowledge level on leprosy was shown to support a favorable attitude toward leprosy.

The findings of this study show that slightly more than half of the study participants were knowledgeable about leprosy. This is not comparable with the findings from previous studies conducted in Ethiopia. ${ }^{7,15}$ A study conducted in Nepal revealed that $42.1 \%$ of the community had good knowledge of leprosy. ${ }^{10}$ Another study done in India showed that $78.94 \%$ of participants had a good quality of knowledge regarding leprosy. ${ }^{16}$ This disagreement could be attributed to the difference in the leprosy burden or effectiveness of the leprosy control program among the countries, where individuals with a high leprosy prevalence area showed a better knowledge than those from low prevalence area. ${ }^{17}$ The use of the different sources of information may generate different levels of individuals' knowledge of leprosy.

Although the majority of the respondents had heard of the disease and had a good understanding of the causative agents, its transmission, and symptoms, only four in ten of them had a favorable attitude toward leprosy. In this study, most of the study participants favored restricting their children from marrying or playing with someone who had a family history of leprosy. This is in agreement with a study conducted in south eastern Ethiopia and Cameroon, where community attitude toward leprosy patients is generally unfavorable. ${ }^{15,18}$ Studies done in central Ethiopia and Nepal revealed that about $3 / 5$ of the study participants had an unfavorable attitude toward leprosy. ${ }^{7,10}$ A study conducted in India reported that $68.59 \%$ of the study participants had a favorable attitude. ${ }^{16}$ The fact that in the current study, almost half of the study participants perceived leprosy as a hereditary disease or a curse from God or due to punishment for sin, might increase stigma toward people with the disease. Furthermore, this poor attitude about leprosy could be related to low literacy levels (77\%) among study participants in the current study area. The results may be supported by the fact that education is highly associated with a favorable attitude toward leprosy. ${ }^{7}$ This may show that despite dramatic changes in the prevalence of leprosy, ${ }^{6}$ there is an insignificant change among the community's perceptions regarding the disease leprosy or leprosy patient. Therefore, it is important to improve the community's attitude toward leprosy, which creates a more supportive environment for the leprosy control program.

In this study, having a high level of knowledge was significantly associated with a favorable attitude toward leprosy $\left(\mathrm{X}^{2}=55.9063, \mathrm{P}=0.001\right)$. It is supported by a study conducted in central Ethiopia, which indicates the existence of a strong positive correlation between the knowledge and attitudes of the community toward leprosy patients. ${ }^{7}$ This finding is also consistent with studies conducted in Nepal and India where good knowledge of leprosy was highly associated with a favorable attitude of 
Table 5 Independent Predictors of Attitude toward Leprosy Among Study Participants in Fedis District from July to August, 2019 $(n=608)$

\begin{tabular}{|c|c|c|c|c|c|}
\hline \multirow[t]{2}{*}{ Attitude } & \multirow[t]{2}{*}{ Independent Predictors } & \multicolumn{4}{|c|}{$95 \% \mathrm{Cl}$} \\
\hline & & OR & Lower & Upper & p-value \\
\hline \multirow[t]{3}{*}{ Would not admit to sitting beside leprosy patient in public transport? } & $\begin{array}{l}\text { Think leprosy is transmitted by } \\
\text { aerosol droplets }\end{array}$ & 2.52 & 1.79 & 3.55 & $<0.001$ \\
\hline & Think leprosy is hereditary & 0.72 & 0.52 & 0.99 & 0.047 \\
\hline & $\begin{array}{l}\text { Think leprosy is due to casual } \\
\text { contact }\end{array}$ & 2.84 & 1.89 & 4.25 & $<0.001$ \\
\hline \multirow[t]{2}{*}{ Would be ashamed if someone had leprosy in your family? } & Think leprosy is hereditary & 1.81 & 1.27 & 2.59 & 0.001 \\
\hline & $\begin{array}{l}\text { Think leprosy is due to prolonged } \\
\text { contact }\end{array}$ & 2.28 & 1.59 & 3.26 & $<0.001$ \\
\hline \multirow[t]{3}{*}{ Would not admit to sharing plate with leprosy patient? } & $\begin{array}{l}\text { Think leprosy is caused by } \\
\text { bacteria }\end{array}$ & 1.68 & 1.19 & 2.38 & 0.003 \\
\hline & $\begin{array}{l}\text { Think leprosy is transmitted by } \\
\text { aerosol droplets }\end{array}$ & 1.41 & 1.01 & 1.96 & 0.040 \\
\hline & Think leprosy is a curse & 0.20 & 0.09 & 0.40 & 0.000 \\
\hline \multirow{4}{*}{$\begin{array}{l}\text { Would not admit to owning a child who married someone from } \\
\text { a family with a history of leprosy? }\end{array}$} & Think leprosy is curse & 0.28 & 0.12 & 0.63 & 0.002 \\
\hline & Think leprosy is hereditary & 1.99 & 1.30 & 3.06 & 0.002 \\
\hline & $\begin{array}{l}\text { Think leprosy is caused by } \\
\text { bacteria }\end{array}$ & 2.90 & 1.88 & 4.48 & $<0.001$ \\
\hline & $\begin{array}{l}\text { Think leprosy is due to prolonged } \\
\text { contact }\end{array}$ & 1.93 & 1.25 & 2.96 & 0.003 \\
\hline \multirow[t]{3}{*}{$\begin{array}{l}\text { Would be ashamed to work with leprosy patient in the same } \\
\text { environment? }\end{array}$} & $\begin{array}{l}\text { Think leprosy is a punishment for } \\
\sin \end{array}$ & 0.41 & 0.26 & 0.64 & $<0.001$ \\
\hline & $\begin{array}{l}\text { Think leprosy is due to prolonged } \\
\text { contact }\end{array}$ & 1.59 & 1.14 & 2.24 & 0.007 \\
\hline & $\begin{array}{l}\text { Think leprosy is transmitted by } \\
\text { aerosol droplets }\end{array}$ & 0.38 & 0.27 & 0.54 & $<0.001$ \\
\hline \multirow[t]{2}{*}{ Would not allow own child to play with a child from leprosy family? } & Think leprosy is curse & 3.49 & 1.36 & 8.96 & 0.009 \\
\hline & $\begin{array}{l}\text { Think leprosy is transmitted by } \\
\text { aerosol droplets }\end{array}$ & 2.32 & 1.60 & 3.37 & $<0.001$ \\
\hline \multirow[t]{2}{*}{ Would admit to helping if someone gets leprosy in the family? } & $\begin{array}{l}\text { Think leprosy is caused by } \\
\text { bacteria }\end{array}$ & 1.82 & 1.07 & 3.09 & 0.025 \\
\hline & Think leprosy is curse & 0.58 & 0.34 & 0.98 & 0.044 \\
\hline
\end{tabular}

the study participants toward leprosy. ${ }^{10,16,19}$ This may point out a need for improving the knowledge of the community on leprosy that could create a favorable attitude toward leprosy in our study area.

In this study, educational status was significantly associated with the level of community knowledge and attitude toward leprosy. This finding is in harmony with the study done in other parts of Ethiopia, which revealed that educational status was significantly associated with the knowledge of and attitude toward leprosy among the general community $(<0.05){ }^{7,15}$ This finding is also in agreement with the study done in Cameroon where those study participants with no level of formal education were the least likely to know that leprosy is curable ( $\mathrm{p}=$ 0.047). ${ }^{18}$ Furthermore, illiteracy and low level of education also showed a significant association with knowledge and attitude of the community toward leprosy in India. $^{20,21} \mathrm{~A}$ study from Nepal also reported that respondents with higher educational status were shown to have a good knowledge of leprosy $(\mathrm{P}<0.001) .{ }^{10}$ Therefore, it is essential to convey knowledge of leprosy among the community through an educational intervention that would bring updated knowledge and methods of leprosy control. $^{22}$ 
Table 6 Association Between Levels of Attitude Regarding Leprosy and Socio-Demographic Characteristics of Study Participants in Fedis District from July to August, $2019(n=608)$

\begin{tabular}{|c|c|c|c|c|c|}
\hline \multirow{2}{*}{ Variables } & \multirow[t]{2}{*}{ Category } & \multicolumn{4}{|c|}{ Level of Attitude Regarding Leprosy } \\
\hline & & Unfavorable, $\mathbf{N}(\%)$ & Favorable, $\mathbf{N}(\%)$ & $\operatorname{COR}(95 \% \mathrm{Cl})$ & $\operatorname{AOR}(95 \% \mathrm{Cl})$ \\
\hline \multirow[t]{2}{*}{ Sex } & Male & I83 (50.83) & $138(55.65)$ & $\mathrm{II}$ & \\
\hline & Female & $177(49.17)$ & $110(44.35)$ & $0.82(0.59-1.14)^{*}$ & $0.7 I(0.48-1.04)$ \\
\hline \multirow[t]{3}{*}{ Age in years } & $18-30$ & $169(46.94)$ & $133(53.63)$ & I & \\
\hline & $31-45$ & $169(46.94)$ & $101(40.73)$ & $0.75(0.54-1.06)^{*}$ & $0.79(0.54-1.14)$ \\
\hline & $>45$ & $22(6.11)$ & $14(5.65)$ & $0.80(0.39-1.64)$ & $0.80(0.37-0.1 .70)$ \\
\hline \multirow[t]{3}{*}{ Current marital status } & Never married & $56(15.56)$ & $26(10.48)$ & I & \\
\hline & Married & $285(79.17)$ & $210(84.68)$ & $1.58(00.96-2.61)$ & \\
\hline & Separated & $19(5.28)$ & $12(4.84)$ & $1.36\left(\begin{array}{lll}0 & 0.57-3.21\end{array}\right)$ & \\
\hline \multirow[t]{2}{*}{ Educational status } & No formal education & $264(73.33)$ & I44(58.06) & I & \\
\hline & Grade I-8 & $54(15.00)$ & $73(29.44)$ & $2.47(1.65-3.72)^{*}$ & $2.72(1.76-4.19)^{* *}$ \\
\hline \multirow{6}{*}{ Occupation } & Secondary \& above & $42(11.67)$ & $3 I(\mid 2.50)$ & $1.35(0.8 \mathrm{I}-2.24)^{*}$ & $0.95(0.35-2.59)$ \\
\hline & Farmer & $252(70.00)$ & I83(73.79) & 1 & \\
\hline & Housewife & $55(15.28)$ & $30(12.10)$ & $0.75(0.46-1.21)$ & $0.75(0.44-1.28)$ \\
\hline & Merchant & 14 (3.89) & $6(2.42)$ & $0.59(0.22-1.562)$ & $0.5 I(0.17-0.1 .46)$ \\
\hline & Civil servant & $31(8.6 I)$ & $28(I I .29)$ & $1.24(0.72-2.14)$ & $1.78(0 \quad 0.60-5.21)$ \\
\hline & Others & $8(2.22)$ & $\mathrm{I}(0.40)$ & $0.17(0.02-1.38)^{*}$ & $0.3 I(0.03-2.8 I)$ \\
\hline \multirow[t]{2}{*}{ Residence } & Rural & $25 I(69.72)$ & $205(82.66)$ & 1 & \\
\hline & Urban & $109(30.28)$ & $43(17.34)$ & $0.48(0.32-0.7 \mathrm{I})^{*}$ & $0.49(0.31-0.75)^{* *}$ \\
\hline
\end{tabular}

Notes: Statistically significant difference $*(P<0.25), * *(P<0.05)$.

Abbreviations: $\mathrm{COR}$, crude odds ratio; $\mathrm{AOR}$, adjusted odds ratio; $\mathrm{Cl}$, confidence interval.

In our study, the unfavorable attitude toward leprosy among urban resident participants was unpredicted (AOR $=0.49,95 \% \mathrm{CI}=0.31-0.75, \mathrm{P}=0.032)$. The possible reason could be that mass media remained to be one of the major sources of information about the disease for most of the study participants in this study. This unexpected finding might show that information, education, and communications conveyed through mass media that influence attitudes positively might be minimal, unlike information from experts. Another reason may be that, the urban health extension programs in leprosy control are still primitive in urban as compared to rural villages.

\section{Limitations}

The strength of this study was that it was a communitybased study, so that the community may receive direct benefits during the study and afterwards; this research focused on the disease neglected by most researchers in Ethiopia. Our study also has some limitations that should be considered; it was not supplemented by qualitative approaches. It would have been stronger if we included people affected by leprosy. Therefore, further studies that include people affected by leprosy and health professionals working on the leprosy control program are required.

\section{Conclusion}

Although more than half of the study participants had a high level of knowledge, only four out of ten participants reported favorable attitudes toward leprosy, with a significant proportion still perceiving leprosy as a hereditary disease. Having at least primary education was found to be associated with having high knowledge and a favorable attitude. Besides, we found that participants with a high level of knowledge displayed a favorable attitude. The finding of urban dwellers having a poor attitude toward leprosy was unexpected.

Therefore, the local health bureau should focus on strategies that improve the community's knowledge of the realities of leprosy, so that attitudes shift to create a more supportive environment for the leprosy control program. As the media remains to be one of the major sources of information about the disease, transmitting more reliable information about the disease by experts is also essential. These can improve the health-seeking behavior of the community and early case detection rate. 


\section{Acknowledgments}

Our sincere appreciation goes to study participants and data collectors for their invaluable contributions. We would also like to thank Oromia Health Bureau, East Haraghe Zonal Health Office/desk, and Fedis District Health Offices for their support during the fieldwork. Finally, we would like to acknowledge the Armauer Hansen Research Institute and Haramaya University for funding this research work.

\section{Disclosure}

The authors report no conflicts of interest.

\section{References}

1. Chaptini C, Marshman G. Leprosy: a review on elimination, reducing the disease burden, and future research. Lepr Rev. 2015;86 (4):307-315.

2. Deribe K, Meribo K, Gebre T, et al. The burden of neglected tropical diseases in Ethiopia, and opportunities for integrated control and elimination. Parasit Vectors. 2012;5(240). doi:10.1186/1756-3305$5-240$

3. Henry M, GalAn N, Teasdale K, Prado R, Amar H, Rays MS. Factors contributing to the delay in diagnosis and continued transmission of leprosy in brazil - an explorative, quantitative, Questionnaire Based Study. PLoS Negl Trop Dis. 2016;10(3):e0004542. doi:10.1371/journal.pntd.0004542

4. Franco-Paredes C, Rodriguez-Morales AJ. Unsolved matters in leprosy: a descriptive review and call for further research. Ann Clin Microbiol Antimicrob. 2016;15:33. doi:10.1186/s12941-016-0149-x

5. Brakel BH, Sihombing B, Djarir H, Beise K, Kusumawardhani L, Yulihane R. Disability in people affected by leprosy: the role of impairment, activity, social participation, stigma and discrimination. Glob Health Action. 2012;5:18394. doi:10.3402/gha.v5i0.18394

6. Sori EA. Review on the Burden of Leprosy in Ethiopia. J Trop Dis. 2019;7(297):2.

7. Atinkut Z, Muna S, Tesema AA. Knowledge, belief, and attitude of the community towards leprosy patients in Gindeberet Woreda, West Shewa Zone. Nurs Health Care Int J. 2018;2(4).

8. Sermrittirong S, Wim H, Brakel V, Rodchan S, Nuncho S. Assessing the attitudes and perceptions of community members and health workers regarding leprosy stigma. IJTDH. 2015;5:11-24. doi:10.9734/ IJTDH/2015/11897

9. World Health Organization: fact sheet. 2019.
10. Singh R, Singh B, Mahato S, Ekpo UF. Community knowledge, attitude, and perceived stigma of leprosy amongst community members living in Dhanusha and Parsa districts of Southern Central Nepal. PLoS Negl Trop Dis. 2019;13(1):e0007075. doi:10.1371/journal.pntd.0007075

11. van 'T Noordende AT, Korfage IJ, Lisam S, Arif MA, Kumar A, van Brakel WH. The role of perceptions and knowledge of leprosy in the elimination of leprosy: a baseline study in Fatehpur district, northern India. PLoS Negl Trop Dis. 2019;13(4):e0007302.

12. ACF. East hararghe nutrition causal analysis report.2014.

13. Canali M, Clavier F. Food insecurity and risk management of smallholder farming systems in Ethiopia. In: GrötzerIDaM, editor. Proceedings of the 9th European IFSA Symposium. Vienna: Universität fürBodenkultur; 2010:1267-1278.

14. East Hararghe zonal Health office annual report. 2017.

15. Tesema AA, Beriso M. Assessment of knowledge and attitude of community on leprosy patients in Kuyera Town, West Arsi Zone, Oromia Region Southeast Ethiopia. Hereditary Genet. 2015;5(1):156.

16. Mohite RV, Mohite VR. Knowledge and attitude of indian rural community towards leprosy after post elimination phase: a survey from Karad Block. India Natl J Community Med. 2016;7 (10):797-801.

17. Saha G, Mandal NK, Dutta RN. Current perceptions and practices (KAP) about leprosy among leprosy patients: a comparative study between high prevalent \& low prevalent Districts of West Bengal. Indian J Lepr. 2015;87:1-16.

18. Tabah EN, Nsagha DS, Zoung-KanyiBissek AC, Njamnshi TN, Njih IN, Pluschke G. Community knowledge, perceptions and attitudes regarding leprosy in rural Cameroon: the case of Ekondotiti and Mbonge health districts in the South-west Region. PLoS Negl Trop Dis. 2018;12(2):e0006233. doi:10.1371/journal.pntd.0006233

19. Noordende A, Korfage I, Lisam S, Arif M, BrakelW AK. The role of perceptions and knowledge of leprosy in the elimination of leprosy: a baseline study in Fatehpur district, northern India. PLoS Negl Trop Dis. 2019;13(4):e0007302.

20. Mohite RVI. Knowledge of slum community toward leprosy: a cross-sectional survey from karad urban block of western maharashtra, India. Asian J Pharm Clin Res. 2018;11(3):357-360. doi:10.22159/ajpcr.2018.v11i3.22494

21. Barkataki P, Kumar SH, Rao P. Knowledge of and attitudes to leprosy among patients and community members: a comparative study in Uttar Pradesh, India. Lepr Rev. 2006;77:62-68.

22. Rajkumar E, Julious S, Salome A, et al. Effects of environment and education on knowledge and attitude of nursing students towards leprosy. Indian J Lepr. 2011;83(1):37-43.
Risk Management and Healthcare Policy

\section{Publish your work in this journal}

Risk Management and Healthcare Policy is an international, peerreviewed, open access journal focusing on all aspects of public health, policy, and preventative measures to promote good health and improve morbidity and mortality in the population. The journal welcomes submitted papers covering original research, basic science, clinical \& epidemiological studies, reviews and evaluations, guidelines, expert opinion and commentary, case reports and extended reports. The manuscript management system is completely online and includes a very quick and fair peer-review system, which is all easy to use. Visit http://www.dovepress.com/testimonials.php to read real quotes from published authors. 